\title{
Fluorinated analogues of lipidic dialkynylcarbinol pharmacophores: synthesis and cytotoxicity in HCT116 cancer cells
}

Pauline Rullière $^{\mathrm{a}}$, François Lizeaux ${ }^{\mathrm{a}}$, Etienne Joly ${ }^{\mathrm{b}}$, Stéphanie Ballereau ${ }^{\mathrm{a}}$, Hafida Gaspard ${ }^{\mathrm{a}}$, Valérie Maraval $^{\mathrm{c}}$, Remi Chauvin ${ }^{\mathrm{c}^{*}}$, Yves Génisson ${ }^{\mathrm{a}^{*}}$

${ }^{a}$ UMR CNRS 5068, LSPCMIB, Université de Toulouse, Université Paul Sabatier, 118 Route de Narbonne, 31062 Toulouse cedex 9, France.

${ }^{\mathrm{b}}$ UMR CNRS 5089, IPBS (Institut de Pharmacologie et de Biologie Structurale), 205 Route de Narbonne, 31077 Toulouse Cedex, France.

${ }^{\mathrm{c}}$ CNRS, LCC (Laboratoire de Chimie de Coordination), 205 route de Narbonne, BP 44099, 31077 Toulouse Cedex 4, France.

\section{chauvin@lcc-toulouse.fr; genisson@chimie.ups-tlse.fr}

Keywords: alkynylcarbinol, fluorine, alkyne, pharmacophore design, cytotoxicity.

Lipidic alkynylcarbinols (LACs) have been identified as potential antitumor compounds, and a thorough understanding of their pharmacophoric environment is now required to elucidate their biological mode of action. In the dialkynylcarbinol (DAC) series, a specific study of the pharmacophore potential has been undertaken by focusing on the synthesis of three fluorinated derivatives followed by their biological evaluation. This work highlights the requirement of an electron-rich secondary carbinol center as a key structure for cytotoxicity in HCT116 cells.

\section{Introduction}

Originally identified as natural bioactive compounds extracted from marine sponges or plant roots [1], lipidic alkynylcarbinols (LACs) constitute a class of potential antitumoral compounds [2]. Over the past few years, efforts have been devoted to the delineation of both optimal structural features [3] and cellular targets [4] of LAC derivatives exhibiting in vitro antiproliferative activity against the HCT116 colon tumor cell line. Noteworthy is a significant and systematic chirality effect, i.e. a dependence of the cytotoxicity on the absolute configuration of the LAC carbinol center. The $\mathrm{IC}_{50}$ value of a racemic LAC sample is thus expected to be roughly two times higher than that of the corresponding eutomer: results in the racemic series are however relevant prior to optimization 


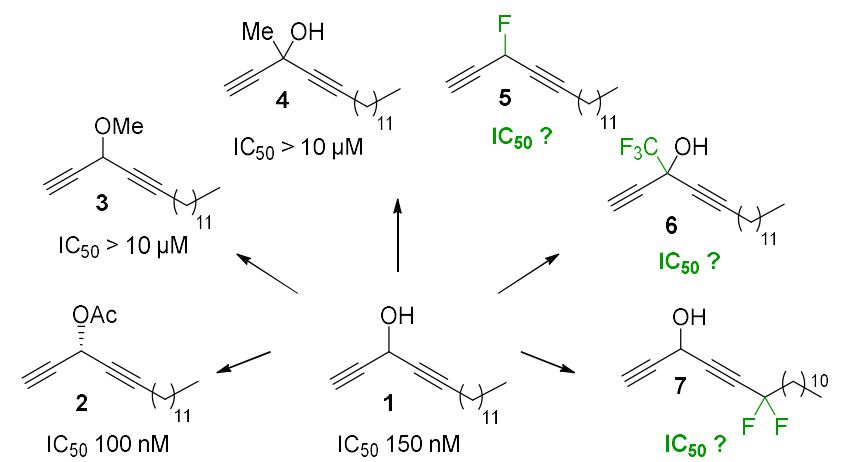

Figure 1. Insight into structure-activity relationships for the cytotoxicity of DACs through systematic pharmacophore modulation.

in the eutomeric series. In the search for the highest potency among various LAC pharmacophore models [3b], the dialkynylcarbinol (DAC) 1 was selected as a reference for its high bioactivity $\left(\mathrm{IC}_{50}=150 \mathrm{nM}\right)$, structural simplicity and ready synthetic accessibility (Figure 1) [5]. The impact on cytotoxicity of further alterations of the DAC warhead and lipidic environment of 1 was then explored (Figure 1). We reported that the acetylated analogue $(S)-\mathbf{2}$ displayed a cytotoxicity in HCT116 similar to that of $(S)-\mathbf{1}$, probably due to in cellulo hydrolysis of the acetate moiety, releasing the free DAC [5]. In contrast, the $O$-methylated derivative 3 proved to be inactive $\left(\mathrm{IC}_{50}>10 \mu \mathrm{M}\right)[6]$. This dramatic effect of a slight modification $(\mathrm{H} \rightarrow \mathrm{Me})$ could be attributed to the stability of the methyl ether group in biological medium, persistently masking the alcohol moiety. Furthermore, the $C$ methylated tertiary alcohol $\mathbf{4}$ displayed the same lack of activity. Overall, the results for $\mathbf{3}$ and $\mathbf{4}$ may thus reflect the carbinol inability to be oxidized, which may be important for its cytotoxicity. Further investigations were thus envisaged through the impoverishment of the DAC warhead by fluorination, the targeted fluorinated analogues being expected to provide a new panel to the systematic study of the DAC pharmacophore.

\section{Results and discussion}

The racemic bis-propargylic fluoride $\mathbf{5}$, deoxyfluorinated analogue of $\mathbf{1}$, was readily obtained by direct treatment of $\mathbf{1}$ with diethylaminosulfur trifluoride (DAST, Scheme 1) $[7]$.

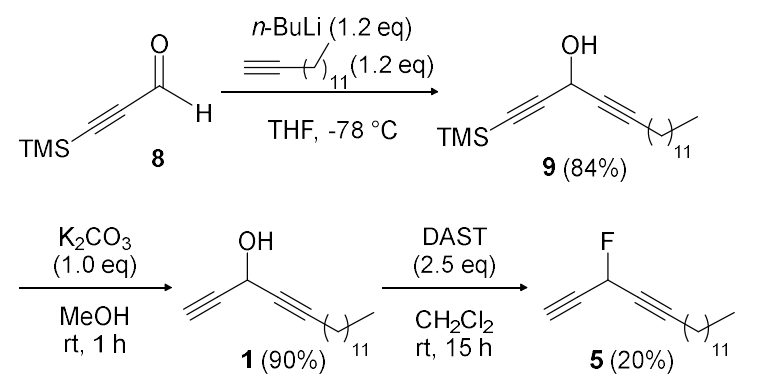

Scheme 1. Synthesis of the deoxyfluorinated analogue 5 of the reference DAC 1.

While full conversion of the alcohol was observed by TLC monitoring, 5 was isolated in low yield. This outcome can be attributed to the particularly high volatility of the hydrocarbon fluoride 5, impeding efficient purification steps and drying procedures. The trifluoro analogue $\mathbf{6}$ of the tertiary alcohol $\mathbf{4}$ was secured by addition of ethynylmagnesium bromide onto the trifluoromethylated ynone 10 (Scheme 2) [8], itself obtained by reaction of a single equivalent of tetradecynyllithium on commercial ethyl trifluoroacetate in the presence of a 
stoichiometric amount of boron trifluoride etherate [9].

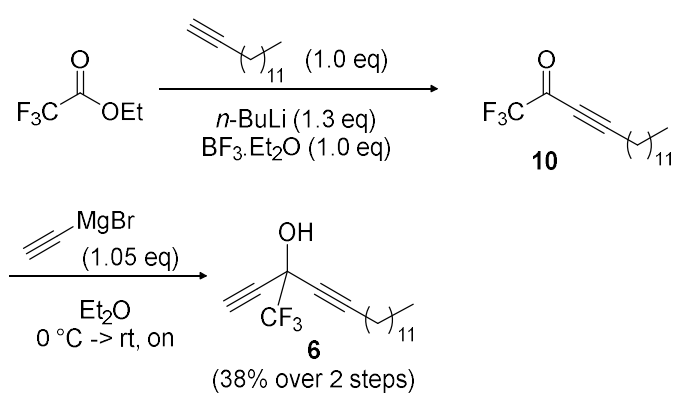

Scheme 2. Synthesis of trifluoromethylated tertiary dialkynylcarbinol 6.

The difluorinated analogue 7 with a $\mathrm{CF}_{2}$ group in place of the propargylic methylene group of $\mathbf{1}$ was obtained through a concise three-step sequence (Scheme 3). 3,3-Difluorotetradec-1yne 12 was prepared by DAST-mediated deoxofluorination of the corresponding ynone 11 [10], and its lithium salt was in turn added to TMS-propynal to give $\mathbf{1 3}$ with $72 \%$ yield (Scheme 3). Desilylation was not observed even under fluorination conditions with an overstoichiometric amount of DAST.
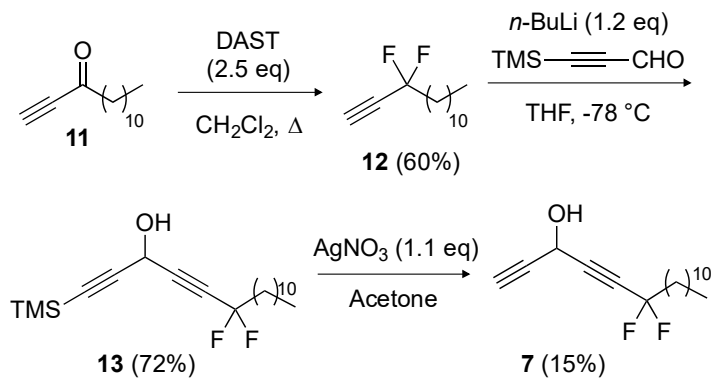

Scheme 3. Synthesis of the difluorinated dialkynylcarbinol 7.

Removal of the TMS group, first attempted under standard basic conditions $\left(\mathrm{K}_{2} \mathrm{CO}_{3} / \mathrm{MeOH}\right)$, led to the formation of an unexpected compound. The latter was identified as the product resulting from the conjugate addition of three molecules of
$\mathrm{MeOH}$ onto the Michael acceptor formed by a base-induced isomerization of the difluorinated alkynylcarbinol 7 [11]. This structural assignment was notably based on several key data from mass spectrometry $(m / z=380),{ }^{1} \mathrm{H}$ NMR (3 $\mathrm{OCH}_{3}$ signals at $3.49,3.40$ and 3.39 ppm, absence of the characteristic terminal acetylenic proton $)$ and ${ }^{13} \mathrm{C}$ NMR $(\mathrm{C}=\mathrm{O}$ signal at $205 \mathrm{ppm})$. Even though several isomers of this structure may be formed, under basic conditions, the structure 14 appears the most likely (Scheme 4).

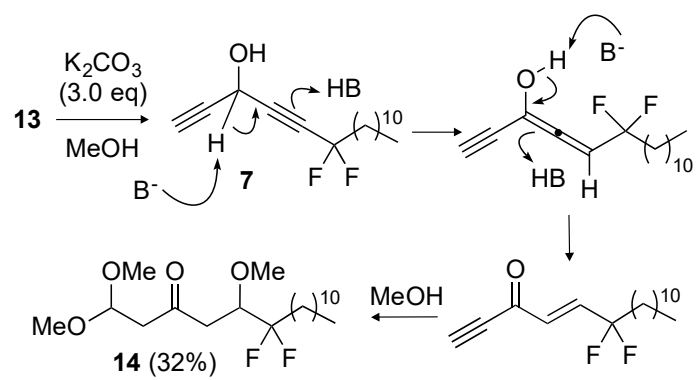

Scheme 4. Base-induced isomerization of 7 and subsequent transformation into the triple Michael adduct 14 upon desilylation of $\mathbf{1 3 .}$

The final desilylation was smoothly accomplished using $\mathrm{AgNO}_{3}$ (Scheme 3). The highly sensitive difluoro-DAC 7 was isolated with $15 \%$ yield after column chromatography. It gave characterization data in full agreement with the expected structure.

The antitumoral potential of the fluorinated DAC analogues 5-7 was then assessed by in vitro cell viability assays in cancer cells (Table 1). The HCT116 cell line was selected as a model. This representative human colon carcinoma cell line is frequently used in the biological evaluation of potential antitumor compounds. In addition, 
cytotoxicity data against HCT116 allow direct comparison with our previous work [2], [3], [4].

Table 1. Cytotoxic activity of DAC analogues in HCT 116 cancer cells.

\begin{tabular}{|c|c|c|c|}
\hline $\begin{array}{c}\text { DAC } \\
\text { derivatives }\end{array}$ & $\mathrm{IC}_{50}[\mu \mathrm{M}]$ & $\begin{array}{c}\text { DAC } \\
\text { derivatives }\end{array}$ & $\mathrm{IC}_{50}[\mu \mathrm{M}]$ \\
\hline$r a c-1$ & $0.15^{\mathrm{a}, 2 \mathrm{a}}$ & $r a c-5$ & $>10^{\mathrm{a}}$ \\
\hline$(S)-2$ & $0.10^{\mathrm{a}, 5}$ & $r a c-6$ & $>10^{\mathrm{a}}$ \\
\hline$r a c-3$ & $>10^{\mathrm{a}, 6}$ & $r a c-7$ & $>10^{\mathrm{a}}$ \\
\hline$r a c-4$ & $>50^{\mathrm{b}, 6}$ & & \\
\hline \multicolumn{4}{|c|}{ 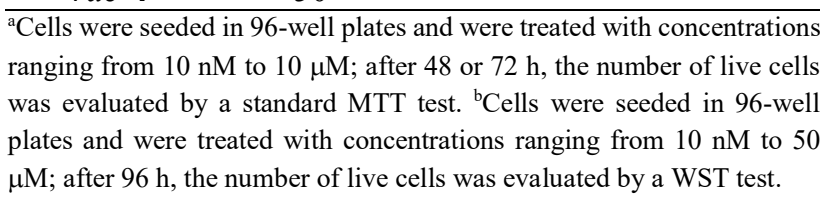 } \\
\hline
\end{tabular}

None of the fluorinated electron-impoverished DAC analogues 5, 6 and 7 displayed any detectable activity at concentrations up to $10 \mu \mathrm{M}$ (Table 1). These results indicate a correlation between the oxidability of DACs or analogues and their cytotoxicity (see Introduction and Figure 1): deoxyfluorination or proximal fluorination of the carbinol center of 1 indeed induces an increase of the oxidation potential in 5-7. These results point to the requirement of an electron-rich carbinol center for inducing cytotoxicity against HCT116 cells.

\section{Conclusions}

The disclosed results highlight key features for cytotoxicity of DAC pharmacophores, i.e. the actual presence, secondary character and electron-richness of the carbinol center. Although the corresponding dialkynylketone was described as non-cytotoxic [6], the essential need for a readily oxidizable carbinol pharmacophore provides a guideline for the design of DACs with improved cytotoxicity. While a prominent criterion for cytotoxic drug candidates is their selectivity towards tumor cells vs. normal cells, the very first criterion is their intrinsic activity. The disclosed fluorinated LACs being basically not cytotoxic, they serve as "negative guidelines" for the design of nonfluorinated candidates, for which this concern will be addressed in due course after optimization.

\section{Experimental part}

\section{General.}

All reagents were obtained from commercial suppliers and used without any further purification. Dichloromethane and tetrahydrofuran (THF) were obtained by filtration through a drying column on a filtration system. Thin-layer chromatography (TLC) analyses were performed on silica gel precoated plates (Merck 60 F254). Visualization of the developed chromatogram was performed by UV light (254 nm) and using $10 \%$ phosphomolybdic acid in EtOH, or aqueous potassium permanganate $\left(\mathrm{KMnO}_{4}\right)$ stain. Flash column chromatography purifications were performed using flash silica gel (SDS 35-70 mm). Nuclear magnetic resonance spectra were recorded in $\mathrm{CDCl}_{3}$ on a Bruker Advance $300 \mathrm{MHz}$ spectrometer. Chemical shifts for ${ }^{1} \mathrm{H}$ NMR spectra are recorded in parts per million (ppm) with the solvent resonance as the reference 
$\mathrm{CDCl}_{3}(\delta=7.26 \mathrm{ppm})$. Data are reported as follows: chemical shift, multiplicity $(\mathrm{s}=$ singlet, $\mathrm{d}=$ doublet, $\mathrm{t}=$ triplet, $\mathrm{q}=$ quartet, $\mathrm{m}=$ multiplet and $\mathrm{br}=$ broad), coupling constant in $\mathrm{Hz}$ and integration. Chemical shifts for ${ }^{13} \mathrm{C}$ NMR spectra are recorded in parts per million using the central peak of $\mathrm{CDCl}_{3}(\delta=77.16 \mathrm{ppm})$ as the reference. All ${ }^{13} \mathrm{C}$ NMR spectra were obtained with complete proton decoupling. Chemical shifts for ${ }^{19} \mathrm{~F}$ NMR spectra are recorded in parts per million (ppm) with an internal standard resonance as the reference fluorobenzene $(\delta=-113.15 \mathrm{ppm})$. IR analysis were run on a Thermo-Nicolet Diamond ATR $\left(4 \mathrm{~cm}^{-1}\right.$ of resolution, 16 scans) equipped with a DTGS detector. High-resolution mass spectrometry (HRMS) was performed on a Thermo-Finnigan MAT 95 XL instrument.

Experimental procedures and characterizations.

3-fluorohexadeca-1,4-diyne (5). DAST (0.1 $\mathrm{mL}, 0.8 \mathrm{mmol}, 2.0$ equiv.) was added to a solution of previously described [5] heptadeca1,4-diyn-3-ol (100 mg, $0.4 \mathrm{mmol})$ in $\mathrm{CH}_{2} \mathrm{Cl}_{2}$ (27 $\mathrm{mL})$ at $-10{ }^{\circ} \mathrm{C}$. The reaction mixture was warmed up to rt and was stirred overnight. Pentane and water $(1: 1)$ were added. The aqueous phase was extracted with pentane and the organic layer was separated. The combined organic layers were dried over $\mathrm{MgSO}_{4}$ and concentrated under reduced pressure. The crude product was submitted to flash chromatography over silica gel (up to pentane/ $\mathrm{Et}_{2} \mathrm{O}, 9: 1$ ) to give compound 5 (20 mg, 20\%) as a colorless oil: $\boldsymbol{R}_{\mathbf{f}}=0.61(100 \%$ pentane). ${ }^{1} \mathbf{H}$ NMR $\left(300 \mathrm{MHz}, \mathrm{CDCl}_{3}\right) \delta 5.68$ (dq, $J=46.9,2.1 \mathrm{~Hz}, 1 \mathrm{H}), 2.74(\mathrm{dd}, J=5.3,2.3$ $\mathrm{Hz}, 1 \mathrm{H}), 2.27$ (qd, $J=7.0,2.1 \mathrm{~Hz}, 2 \mathrm{H}), 1.6-1.45$ $(\mathrm{m}, 2 \mathrm{H}), 1.42-1.22(\mathrm{~m}, 18 \mathrm{H}), 0.95-0.80(\mathrm{~m}, 3 \mathrm{H})$. ${ }^{13}$ C NMR $\left(75 \mathrm{MHz}, \mathrm{CDCl}_{3}\right) \delta 86.3,83.3(\mathrm{~d}, J=$ $252.0 \mathrm{~Hz}), 77.1,72.3,68.2,52.3,29.7,29.6$, 29.2, 29.0, 28.9, 28.6, 28.4, 18.8, 18.5. ${ }^{19}$ F NMR $\left(282 \mathrm{MHz}, \mathrm{CDCl}_{3}\right) \delta-160.4(\mathrm{~m}) . \mathbf{M S}\left(\mathrm{DCI}-\mathrm{NH}_{3}\right.$ neg.): $m / z 249$ (M-1). FTIR ( $\left.\mathrm{cm}^{-1}\right)$ (neat): 3300, 2922, 2853, 2319, 2242, 2135, 1467, 1313, 1154, 999, 934.

\section{3-(trifluoromethyl)heptadeca-1,4-diyn-3-ol}

(6). An ethynylmagnesium bromide solution (1.88 mL, 1.05 equiv., $0.5 \mathrm{M}$ in THF) was added to a solution of 1,1,1-trifluorohexadec-3-yn-2one 10 (260 mg, $0.90 \mathrm{mmol})$ in THF $(5 \mathrm{~mL})$ under $\mathrm{N}_{2}$ atmosphere at $-78^{\circ} \mathrm{C}$. The mixture was stirred at $\mathrm{rt}$ overnight. A saturated aqueous $\mathrm{NH}_{4} \mathrm{Cl}$ solution was added, the aqueous layer was extracted with $\mathrm{Et}_{2} \mathrm{O}$ and the organic layer was separated. The combined organic layers were dried over $\mathrm{MgSO}_{4}$ and concentrated under reduced pressure. The crude product was submitted to flash chromatography over silica gel (up to pentane/Et $2 \mathrm{O}, 8: 2$ ) to give trifluoromethylated dialkynylcarbinol $\mathbf{6}$ (108 mg, 38\% over two steps) as a brown oil: $\boldsymbol{R}_{\mathbf{f}}=0.5$ (pentane/Et $\left.{ }_{2} \mathrm{O}, 8: 2\right) .{ }^{1} \mathbf{H}$ NMR (300 MHz, $\left.\mathrm{CDCl}_{3}\right) \delta 2.94(\mathrm{~s}, 1 \mathrm{H}), 2.68(\mathrm{~s}, 1 \mathrm{H}), 2.26(\mathrm{t}, J=$ $7.1 \mathrm{~Hz}, 2 \mathrm{H}), 1.63-1.53(\mathrm{~m}, 2 \mathrm{H}), 1.43-1.27$ (m, $18 \mathrm{H}), 0.92(\mathrm{t}, J=6.7 \mathrm{~Hz}, 3 \mathrm{H}) .{ }^{13} \mathbf{C}$ NMR $(75$ $\left.\mathrm{MHz}, \mathrm{CDCl}_{3}\right) \delta 122.0(\mathrm{q}, J=285.0 \mathrm{~Hz}), 88.9$, 74.4, 72.8, 68.1, 32.1, 29.8, 29.8, 29.7, 29.6, 29.5, 29.1, 28.9, 27.9, 22.8, 18.7. HRMS (DCI- 
$\left.\mathrm{CH}_{4}\right)$ : calcd for $\mathrm{C}_{18} \mathrm{H}_{28} \mathrm{~F}_{3} \mathrm{O}[\mathrm{M}+\mathrm{H}]^{+}: 317.2092$ $\mathrm{m} / \mathrm{z}$, found: $317.2102 \mathrm{~m} / \mathrm{z}$. FTIR $\left(\mathrm{cm}^{-1}\right)$ (neat): 3408 (br), 3307, 2924, 2854, 2246, 2129, 1266, 1193, 1173, 1073, 998.

6,6-difluoroheptadeca-1,4-diyn-3-ol (7). 6,6Difluoro-1-(trimethylsilyl)heptadeca-1,4-diyn3-ol 13 (320 mg, $0.9 \mathrm{mmol}$ ) was stirred overnight with $\mathrm{AgNO}_{3}$ (168 mg, $0.99 \mathrm{mmol}, 1.1$ equiv.) in wet acetone $(5 \mathrm{~mL})$. The reaction was quenched with water and $\mathrm{Et}_{2} \mathrm{O}$ was added. The aqueous layer was extracted with $\mathrm{Et}_{2} \mathrm{O}(3 \times 4 \mathrm{~mL})$ and the organic layer was separated. The combined organic layers were dried over $\mathrm{MgSO}_{4}$ and concentrated under reduced pressure. The crude product was submitted to flash chromatography over $\mathrm{SiO}_{2}$ (with a gradient elution up to pentane/Et $2 \mathrm{O}, 9: 1)$ to give the desired product 7 (38 mg, 15\%) as a brown oil: $\boldsymbol{R}_{\mathbf{f}}=0.5$ (pentane/Et $2 \mathrm{O}$ 9:1). ${ }^{1} \mathbf{H}$ NMR (300 MHz, $\mathrm{CDCl}_{3}$ ) $\delta 5.22-5.16(\mathrm{~m}, 1 \mathrm{H}), 2.62(\mathrm{~d}, J=2.4 \mathrm{~Hz}, 1 \mathrm{H})$, $2.31(\mathrm{~d}, J=8.0 \mathrm{~Hz}, 1 \mathrm{H}), 2.14-1.91(\mathrm{~m}, 2 \mathrm{H})$, $1.62-1.45(\mathrm{~m}, 2 \mathrm{H}), 1.28(\mathrm{~d}, J=12.2 \mathrm{~Hz}, 16 \mathrm{H})$, $0.88(\mathrm{t}, J=6.7 \mathrm{~Hz}, 3 \mathrm{H}) .{ }^{13} \mathbf{C}$ NMR $(75 \mathrm{MHz}$, $\left.\mathrm{CDCl}_{3}\right) \delta 114.8(\mathrm{t}, J=233.4 \mathrm{~Hz}), 83.1(\mathrm{t}, J=6.9$ $\mathrm{Hz}), 79.4(\mathrm{t}, J=2.3 \mathrm{~Hz}), 77.8,74.2,51.9,39.1(\mathrm{t}$, $J=25.5 \mathrm{~Hz}), 32.1$, 29.7, 29.6, 29.5, 29.4, 29.1, 22.8, $22.7(\mathrm{t}, J=3.5 \mathrm{~Hz}), 14.3 .{ }^{19} \mathbf{F}$ NMR $(282$ $\left.\mathrm{MHz}, \mathrm{CDCl}_{3}\right) \delta \quad-83.99(\mathrm{td}, J=15.1,3.8 \mathrm{~Hz})$. HRMS (DCI-CH4): calcd for $\mathrm{C}_{17} \mathrm{H}_{27} \mathrm{~F}_{2} \mathrm{O}$ $[\mathrm{M}+\mathrm{H}]^{+}: 285.2030 \mathrm{~m} / z$, found: $285.2027 \mathrm{~m} / \mathrm{z}$. FTIR $\left(\mathrm{cm}^{-1}\right)$ (neat): 3364 (br), 3310, 2925, 2855, 2262, 2126, 1031.

\section{1,1,1-trifluorohexadec-3-yn-2-one}

According to previously reported reaction conditions [9], to a stirred solution of 1tetradecyne $(1.73 \mathrm{~mL}, 7.04 \mathrm{mmol})$ in THF (11 $\mathrm{mL})$ was added $n$-butyllithium $(3.7 \mathrm{~mL}, 9.15$ $\mathrm{mmol}, 2.5 \mathrm{M}$ in hexanes) dropwise at $-78^{\circ} \mathrm{C}$. The resulting solution was stirred at the same temperature for $30 \mathrm{~min}$, at which time a solution of ethyl trifluoroacetate $(0.84 \mathrm{~mL}, 7.04 \mathrm{mmol})$ and boron trifluoride diethyl etherate $(0.87 \mathrm{~mL}$, $7.04 \mathrm{mmol})$ in THF $(2 \mathrm{~mL})$ was introduced dropwise. After reaction completion (ca. 1 h), a saturated aqueous $\mathrm{NH}_{4} \mathrm{Cl}$ solution was added. The aqueous layer was separated and extracted with $\mathrm{Et}_{2} \mathrm{O}$. The combined organic extracts were washed with brine, dried over $\mathrm{MgSO}_{4}$, filtered and concentrated under reduced pressure to give the crude product, which was purified by flash chromatography on silica gel (up to pentane/Et $\left.{ }_{2} \mathrm{O}, 8: 2\right)$ to afford desired trifluoromethylketone $\mathbf{1 0}(260 \mathrm{mg}, 13 \%)$. Spectral data were comparable with those previously reported in the literature [9b] and are not described in detail.

Tetradec-1-yn-3-one (11). Dess-Martin periodinane reagent $(202 \mathrm{mg}, 0.48 \mathrm{mmol}, 1$ equiv.) was added to a solution of tetradec-1-yn3-ol (100 mg, $0.48 \mathrm{mmol})$ in $\mathrm{CH}_{2} \mathrm{Cl}_{2}(2 \mathrm{~mL})$ under $\mathrm{N}_{2}$ atmosphere. The mixture was stirred at rt overnight. A saturated aqueous $\mathrm{NaHCO}_{3}$ solution was added, the aqueous layer was extracted with $\mathrm{CH}_{2} \mathrm{Cl}_{2}$ and the organic layer was separated. The combined organic layers were 
dried over $\mathrm{MgSO}_{4}$ and concentrated under reduced pressure. The crude product was submitted to flash chromatography over silica gel (up to pentane/Et $2 \mathrm{O}, 8: 2$ ) to give ketone $\mathbf{1 1}(86$ $\mathrm{mg}, 87 \%)$ as a yellow oil: $\quad \boldsymbol{R}_{\mathbf{f}}=0.57$ (pentane/Et $2 \mathrm{O}, 8: 2) .{ }^{1} \mathbf{H}$ NMR $(300 \mathrm{MHz}$, $\left.\mathrm{CDCl}_{3}\right) \delta 3.19(\mathrm{~s}, 1 \mathrm{H}), 2.58(\mathrm{t}, J=7.4 \mathrm{~Hz}, 1 \mathrm{H})$, 1.67 (t, $J=7.2 \mathrm{~Hz}, 2 \mathrm{H}), 1.57$ (s, $1 \mathrm{H}), 1.33-1.22$ (m, 16H), 0.95 (t, $J=6.0 \mathrm{~Hz}, 3 \mathrm{H}) .{ }^{13} \mathbf{C}$ NMR $(75$ $\left.\mathrm{MHz}, \mathrm{CDCl}_{3}\right) \delta 187.8,81.6,78.4,45.6,32.0$, 29.7, 29.5, 29.4, 29.0, 23.9, 22.8, 14.3. FTIR $\left(\mathrm{cm}^{-1}\right)$ (neat): 3299, 3255, 2853, 2924, 2093, 1683, 1466 .

3,3-difluorotetradec-1-yne (12). Tetradec-1-yn3-one 11 (1.5 g, $7.2 \mathrm{mmol})$ and DAST $(2.23 \mathrm{~mL}$, 18 mmol, 2.5 equiv.) were heated neat at $56^{\circ} \mathrm{C}$ and stirred under nitrogen atmosphere over $5 \mathrm{~h}$. The crude product was submitted to flash chromatography over silica gel (up to pentane $\left./ \mathrm{Et}_{2} \mathrm{O}, 95: 5\right)$ to give the difluorinated product 12 $(1.0 \mathrm{~g}, 60 \%)$ as a yellow oil: $\boldsymbol{R}_{\mathbf{f}}=0.57$ (pentane/Et $2 \mathrm{O}, 8: 2) .{ }^{1} \mathbf{H}$ NMR $\left(300 \mathrm{MHz}, \mathrm{CDCl}_{3}\right)$ $\delta 2.74(\mathrm{t}, J=4.9 \mathrm{~Hz}, 1 \mathrm{H}), 2.10-1.94(\mathrm{~m}, 2 \mathrm{H}), 1.60-$ $1.50(\mathrm{~m}, 2 \mathrm{H}), 1.39-1.22(\mathrm{~m}, 16 \mathrm{H}), 0.93(\mathrm{t}, J=5.4 \mathrm{~Hz}$, $3 \mathrm{H}) .{ }^{13} \mathbf{C}$ NMR $\left(75 \mathrm{MHz}, \mathrm{CDCl}_{3}\right) \delta 114.6(\mathrm{t}, J=232.0$ $\mathrm{Hz}), 75.1(\mathrm{t}, J=6.8 \mathrm{~Hz}), 39.2(\mathrm{t}, J=25.4 \mathrm{~Hz}), 32.1$, 29.9, 29.7, 29.6, 29.5, 29.1, 23.0, 14.3. ${ }^{19} \mathbf{F}$ NMR (282 $\left.\mathrm{MHz}, \mathrm{CDCl}_{3}\right) \delta-83.9(\mathrm{td}, J=15.1 \mathrm{~Hz}, 5.0 \mathrm{~Hz})$. FTIR $\left(\mathrm{cm}^{-1}\right)$ (neat): 3305, 2923, 2854, 2134, 2095, $1685,1466$.

\section{6,6-difluoro-1-(trimethylsilyl)heptadeca-1,4-}

diyn-3-ol (13). $n$-Butyllithium solution $(2.6 \mathrm{~mL}$, $0.65 \mathrm{mmol}, 1.2$ equiv., $2.5 \mathrm{M}$ in hexanes) was added to a solution of 3,3-difluorotetradec-1-yne
12 (125 mg, $0.54 \mathrm{mmol})$ in THF (15 mL) under $\mathrm{N}_{2}$ atmosphere at $-78^{\circ} \mathrm{C}$. After 45 min of stirring, 3-(trimethylsilyl) propiolaldehyde $(0.1 \mathrm{~mL}, 3.17$ mmol, 5.8 equiv.) was added at $-78{ }^{\circ} \mathrm{C}$. Temperature and stirring were maintained during 30 min. A saturated aqueous $\mathrm{NH}_{4} \mathrm{Cl}$ solution was added, the aqueous layer was extracted with $\mathrm{Et}_{2} \mathrm{O}$ and the organic layer was separated. The combined organic layers were dried over $\mathrm{MgSO}_{4}$ and concentrated under reduced pressure. The crude product was submitted to flash chromatography over silica gel (up to pentane/Et $2 \mathrm{O}, 9: 1$ ) to give dialkynylcarbinol 13 (140 mg, 72\%) as a brown oil: $\boldsymbol{R}_{\mathrm{f}}=0.47$ (pentane/Et $2 \mathrm{O}, 9:$ 1). ${ }^{1} \mathbf{H}$ NMR $(300 \mathrm{MHz}$, $\left.\mathrm{CDCl}_{3}\right) \delta 5.17(\mathrm{dt}, J=7.5,3.7 \mathrm{~Hz}, 1 \mathrm{H}), 2.26(\mathrm{~d}$, $J=7.3 \mathrm{~Hz}, 1 \mathrm{H}$ ), 2.12-1.96 (m, 2H), 1.60-1.49 (m, $2 \mathrm{H}), 1.37-1.22(\mathrm{~m}, 16 \mathrm{H}), 0.94(\mathrm{t}, J=13.4 \mathrm{~Hz}$, $3 \mathrm{H}), 0.20(\mathrm{~s}, 9 \mathrm{H}) .{ }^{13} \mathbf{C}$ NMR $\left(75 \mathrm{MHz}, \mathrm{CDCl}_{3}\right) \delta$ $127.2,117.8,114.7,111.6,100.0,91.2,83.5(t, J$ $=7.0 \mathrm{~Hz}), 77.3,52.3,39.1(\mathrm{t}, J=25.5 \mathrm{~Hz}), 31.9$, 29.6, 29.5, 29.4, 29.0, 23.3, 14.1, 0.0. ${ }^{19} \mathbf{F}$ NMR $\left(282 \mathrm{MHz}, \mathrm{CDCl}_{3}\right) \delta-83.79(\mathrm{td}, J=15.0 \mathrm{~Hz}, 3.6$ Hz). FTIR ( $\left.\mathrm{cm}^{-1}\right)$ (neat): 3390 (br), 2926, 2856, 1467, 1252, 1043, 845, 761.

\section{6,6-difluoro-1,1,5-trimethoxyheptadecan-3- \\ one (14): 6,6-Difluoro-1-}

(trimethylsilyl)heptadeca-1,4-diyn-3-ol 13 (140 mg, $409 \mu$ mol) was stirred overnight with $\mathrm{K}_{2} \mathrm{CO}_{3}$ (169 mg, $1.2 \mathrm{mmol}, 3$ equiv.) and $\mathrm{MeOH}(2 \mathrm{~mL}$ ). A saturated aqueous $\mathrm{NH}_{4} \mathrm{Cl}$ solution was added, the aqueous layer was extracted with $\mathrm{Et}_{2} \mathrm{O}$ ( 3 x 5 $\mathrm{mL}$ ) and the organic layer was separated. The 
combined organic layers were dried over $\mathrm{MgSO}_{4}$ and concentrated under reduced pressure. The crude product was submitted to flash chromatography over $\mathrm{SiO}_{2}$ (up to pentane/Et $t_{2} \mathrm{O}$, $9: 1)$ to give the triple Michael adduct $14(50 \mathrm{mg}$, $33 \%)$ as a brown oil: $\boldsymbol{R}_{\mathbf{f}}=0.5$ (pentane/ $\left./ \mathrm{Et}_{2} \mathrm{O} 9: 1\right)$.

${ }^{1} \mathbf{H}$ NMR $\left(300 \mathrm{MHz}, \mathrm{CDCl}_{3}\right) \delta 4.84(\mathrm{t}, J=5.6$ $\mathrm{Hz}, 1 \mathrm{H}), 4.05-3.92(\mathrm{~m}, 1 \mathrm{H}), 3.49$ (s, 3H), 3.40 (s, 3H), 3.39 (s, 3H), $2.81(\mathrm{dd}, J=5.6,2.0 \mathrm{~Hz}$, $2 \mathrm{H}), 2.76(\mathrm{~d}, J=5.8 \mathrm{~Hz}, 2 \mathrm{H}), 2.07-1.72(\mathrm{~m}$, $2 \mathrm{H}), 1.59-1.47(\mathrm{~m}, 2 \mathrm{H}), 1.33-1.19(\mathrm{~m}, 16 \mathrm{H})$, 0.97 (t, $J=6.7 \mathrm{~Hz}, 3 \mathrm{H}) .{ }^{13} \mathrm{C}$ NMR $(75 \mathrm{MHz}$, $\left.\mathrm{CDCl}_{3}\right) \delta 204.5(\mathrm{C}=\mathrm{O}), 125.7(\mathrm{t}, J=245.9 \mathrm{~Hz}$, $\mathrm{CF}_{2}$ ), 101.4, $77.4(\mathrm{dd}, J=30.4,27.8 \mathrm{~Hz}), 60.0$ (OMe), 54.2 (OMe), 53.8 (OMe), 47.4, 43.7 (dd, $J=3.8,1.9 \mathrm{~Hz}), 32.7$ (t, $J=24.1 \mathrm{~Hz}), 32.0,29.7$, 29.6, 29.6, 29.5, 29.5, 22.8, $21.4(\mathrm{t}, J=4.3 \mathrm{~Hz})$, 14.3. MS (DCI-NH ${ }_{3}$ neg.): $m / z 280$ (M-1).

Acknowledgements. The Foundation ARC for Research on Cancer is acknowledged for a postdoctoral fellowship supporting P.R. research.

\section{References}

[1] (a) Kuklev DV, Dembitsky VM. Epoxy acetylenic lipids: Their analogues and derivatives. Prog Lipid Res. 2014;56:67-91. (b) Kuklev DV, Domb AJ, Dembitsky VM. Bioactive acetylenic metabolites. Phytomedicine. 2013;20(13):1145-59. (c) Siddiq A, Dembitsky V. Acetylenic anticancer agents. Anticancer Agents Med Chem. 2008;8(2):132-170. (d) Shun ALKS, Tykwinski RR. Synthesis of Naturally Occurring Polyynes. Angew Chem Int Ed. 2006;45(7):1034-57. (e) Dembitsky VM.
Anticancer activity of natural and synthetic acetylenic lipids. Lipids. 2006;41(10):883-924.

[2] El Arfaoui D, Listunov D, Fabing I, Oukessou M, Frongia C, Lobjois V, Samson A, Ausseil F, Ben-Tama A, El Hadrami EM, Chauvin R, Génisson Y. Identification of Chiral Alkenyl- and Alkynylcarbinols as Pharmacophores for Potent Cytotoxicity. ChemMedChem. 2013;8(11):1779-86. (b) Hallock YF, Cardellina JH, Balaschak MS, Alexander MR, Prather TR, Shoemaker RH, Boyd MR. Antitumor Activity and Stereochemistry of Acetylenic Alcohols from the Sponge Cribrochalina vasculum. J Nat Prod. 1995;58(12):1801-7. (c) Aiello A, Fattorusso E, Menna M, Pansini M. Further Bioactive Acetylenic Compounds from the Caribbean Sponge Cribrochalina vasculum. J Nat Prod. 1992;55(9):1275-80. (d) Gunasekera SP, Faircloth GT. New acetylenic alcohols from the sponge Cribrochalina vasculum. J Org Chem. 1990;55(25):6223-5.

[3] (a) Listunov D, Maraval V, Chauvin R, Génisson Y. Chiral alkynylcarbinols from marine sponges: asymmetric synthesis and biological relevance. Nat Prod Rep. 2015;32(1):49-75. (b) Listunov D, Joly E, Rullière P, Gaspard H, Bernardes-Génisson V, Génisson Y, Maraval V, Chauvin R. From natural to artificial antitumor lipidic alkynylcarbinols: asymmetric synthesis, enzymatic resolution and refined SARs. Synthesis. 2018;50(16):3114 30 .

[4] Listunov D, Mazères S, Volovenko Y, Joly E, Génisson Y, Maraval V, Chauvin R. Fluorophore-tagged pharmacophores for antitumor cytotoxicity: Modified chiral lipidic dialkynylcarbinols for cell imaging. Bioorg Med Chem Lett. 2015;25(20):4652-6.

[5] Bourkhis M, Gaspard H, Rullière P, de Almeida DKC, Listunov D, Joly E, Abderrahim R, de Mattos MC, de Oliveira MCF, Maraval V, Chauvin R, Génisson Y. Skeletal Optimization of Cytotoxic Lipidic Dialkynylcarbinols. ChemMedChem. 2018;13(11):1124-30.

[6] Listunov D, Billot C, Joly E, Fabing I, Volovenko Y, Génisson Y, Maraval V, Chauvin R. Extended structural 
modulation of bio-inspired chiral lipidic alkynylcarbinols

as antitumor pharmacophores. Tetrahedron. 2015;71(41):7920-30.

[7] (a) Madiot V, Lesot P, Grée D, Courtieu J, Grée R. Highly enantioselective propargylic monofluorination established by carbon-13 and fluorine-19 NMR in chiral liquid crystals. Chem Commun. 2000;(2):169-70. (b) Prakesch M, Kerouredan E, Grée D, Grée R, DeChancie J, Houk KN. The propargylic route as efficient entry to monofluoro and gem-difluoro compounds: mechanistic considerations. J Fluor Chem. 2004;125(4):537-41. (c) Fauq AH, Singh RP, Meshri DT. Diethylaminosulfurtrifluoride. e-EROS Encyclopedia of Reagents for Organic Synthesis. 2004;1 :1-14.

[8] (a) Rives A, Baglai I, Barthes C, Maraval V, SaffonMerceron N, Saquet A, Voitenko Z, Volovenko Y, Chauvin R. Carbo-cyclohexadienes vs. carbo-benzenes: structure and conjugative properties. Chem Sci. 2015;6(2):1139-49. (b) Maraval V, Leroyer L, Harano A, Barthes C, Saquet A, Duhayon C, Shinmyozu T, Chauvin R. 1,4-Dialkynylbutatrienes: Synthesis, Stability, and Perspectives in the Chemistry of carbo-Benzenes. Chem Eur J. 2011;17(18):5086-100.

[9] (a) Hsieh M-T, Kuo S-C, Lin H-C. Solvent- and Transition Metal Catalyst-Dependent Regioselectivity in the $[3+2]$ Cyclocondensation of Trifluoromethyl- $\alpha, \beta-$ ynones with Hydrazines: Switchable Access to 3- and 5Trifluoromethylpyrazoles. Adv Synth Catal. 2015;357(4):683-9. (b) Linderman RJ, Lonikar MS. Addition of organocuprates to acetylenic di- and trifluoromethyl ketones. Regiospecific synthesis of $\beta, \beta$ disubstituted unsaturated fluoro ketones. J Org Chem. 1988;53(26):6013-22.

[10] Grée D, Grée R. Effect of fluorine or oxygen atom(s) in propargylic position on the reactivity in click chemistry. Tetrahedron Lett. 2010;51(17):2218-21.

[11] El Dine A N, Khalaf A, Grée D, Tasseau O, Fares F, Jaber N, Lesot P, Hachem A, Grée R. Synthesis of enones, pyrazolines and pyrrolines with gem-difluoroalkyl side chains. Beilstein J Org Chem. 2013;9:1943-8. 